\title{
Phenotypic and genotypic identification of yeasts isolated from some dairy products
}

\author{
K. A. A. Khater 1,*, Y. A. Abd El-Tawab ${ }^{2}$ and A. A. Abd El-Dayem ${ }^{2}$ \\ ${ }^{1}$ Dairy Science Department, Faculty of Agriculture, Al-Azhar University, Cairo, Egypt \\ 2 Dairy Science Department, Faculty of Agriculture, Al-Azhar University, Assuit, Egypt \\ *Correspondence: khaterkhater.5@azhar.edu.eg (K. Khater)
}

\begin{abstract}
Yeast classification is traditionally based on their physiological and biochemical profiles. Recently, molecular methods have been successfully applied to yeast strain typing and identification. The aim of this paper was to characterize four yeast strains isolated from dairy products by classical and molecular methods. The preliminary examination involved macroscopic appearances of colonies on solid media and microscopic feature of the cells. Physiological characterization was mainly performed by assessing the ability to use certain sugars semi-anaerobically, the ability to use organic compounds as sole carbon source for aerobic growth, urea hydrolysis, growth at high concentrations of glucose and the ability to growth at non-optimal temperatures $\left(37^{\circ} \mathrm{C}\right.$ and $\left.42^{\circ} \mathrm{C}\right)$. From results obtained it could be stated that, although there were some variations in biochemical patterns all tested yeasts were classified either as S. cerevisiae or and G. candidum with $95-99 \%$ of probability. For molecular identification only three specific primer pairs and one universal primer were used. The identification was carried out based on ITS 1 partial sequence, 5.8 S rRNA gene and ITS 2 complete sequence and large subunit rRNA gene sequence analysis. The results obtained showed that the product of $S$. cerevisiae scored $600 \mathrm{bp}$ in lan (1and 2) using 5.8 S rRNA gene with primer ITS and NL2, while G. candidum scored 600 bp in lan (3and 4) using 18S rDNA gene with primer (18S ITS1 - 28S ITS 2). However, the sequence analysis of the four identified yeast strains was submitted to Genebank in the NCBI database. They have been accepted to be deposited and released in Genebank under four new accession numbers, actually KY441458, MF380234 for S. cerevisiae and MF383376, MF383368 for G. candidum strains. In conclusion, Strains were locally isolated from Egyptian resources to increase the additive value of the Egyptian microbial wealth.
\end{abstract}

Keywords: Dairy products; G. candidum; S. cerevisiae.

\section{INTRODUCTION}

Nowadays the impact of yeasts in foods is beyond original and popular notions of bread, beer and wine fermentations by Saccharomyces cerevisiae. There is an increasing interest in using yeasts as new sources for improvement of food properties such as: flavor, vitamins content and as agents for the control of food spoilage by their anti-fungal activity (Querol and Fleet, 2006).

In addition, the use of yeasts as potential probiotics, have also been reviewed (Psomas et al., 2001 and Kumura et al.2004). In this concern it is believed that dairy products are ideal for delivering the probiotics, therefore probiotic yeasts have been increasingly incorporated into dairy products as dietary adjuncts.

Yeasts are traditionally characterized and identified by morphological and physiological criteria (Kurtzman and Fell, 1998). However, these conventional criteria are often unable to discriminate at a subspecies level and provide doubtful identification (Psoma et al., 2001 and Van der AaKuhle et al., 2001).
Recently, molecular methods have become available, it extends from determining DNA composition to sequencing of parts and even the whole genome of yeast (Kurtzman, 2006). However, molecular techniques have been increasingly and successfully applied to yeast strains typing and identification (Iosepa et al., 2000; Pataro et al., 2000 and Ouwehand et al., 2002). Therefore, the target of the present work was to characterize the tested yeast strains by classical (morphology, biochemical features) and molecular methods.

\section{MATERIALS AND METHODS}

\section{Materials}

Yeast strains: Yeast strains named Y30, Y42, Y67 and Y72 were previously isolated from dairy products such as: cream, raw milk and milk ripe.

As reference strains we used Saccharomyces cervisiae ATCC MYA-795 and Geotrichum candidum ATCC ADE-115, were obtained from 
Botany Dept., Fac. of Science, Al-Azhar Univ. Assiut.

\section{Media}

Glucose peptone yeast extract Agar (GPY Agar): This medium is composed of: glucose $40 \mathrm{~g}$; peptone $5 \mathrm{~g}$, yeast extract $5 \mathrm{~g}$, and $20 \mathrm{~g}$ of agar: $\mathrm{pH} 5-6$.

Carbohydrates: Glucose, sucrose, lactose, maltose, galactose, D-Xylose were provided from SIGMA, USA, while, glycerol, manitol, methanol, citrate, and starch were delivered from Difco Laboratories, Detroit, Michigan, USA.

\section{Nitrogen compounds}

L-lysine, ethylamine, tryptophan, nitrite and nitrate were obtained from SIGMA, USA.

\section{Methods}

\section{Morphological characteristics of tested yeast cultures}

Fresh yeast cultures were cultivated on YPGA medium in petri dishes, and the surface of the colonies were observed. The yeasts were also inoculated in liquid YPG medium for determination of their characteristics The microscopic appearance of the cells was examined after growth in the YPG medium for 2-3 days at $25^{\circ} \mathrm{C}$ (Guilliermond, 2003).

\section{Fermentati Tested strains on of carbohydrates:}

The ability of yeast to ferment different sugars were tested using $2 \%(\mathrm{w} / \mathrm{v})$ sugar solution were determined by using Durham tubes in fermentation basal medium as described by Suh et al. (2007), bromothymol blue was added, inoculated with $0.1 \mathrm{~mL}$ of cell suspension and incubated at $25-28^{\circ} \mathrm{C}$ for 28 days.

\section{Assimilation of carbon and nitrogen sources:}

The ability of yeast cultures to grow aerobically on carbon or nitrogen as the sole source of energy where cared out by replica plate method as described by (Kurtzman et al 2011). Yeast nitrogen base (YNB) and Yeast carbon base (YCB) as described by Lodder and Kreger (1952) were used for testing the assimilation of either carbon or nitrogen source by yeasts. The plates which containing different carbon or nitrogen source in carbon or nitrogen basal agar medium was inoculated by the test yeast cultures.

Inspection of the colonies growth, and compared with control plates (without carbon or nitrogen sources) after incubation period of $2-6$ days at $28^{\circ} \mathrm{C}$ was adopted.

\section{Complementary tests}

Growth at non-optimal temperatures $\left(37^{\circ} \mathrm{C}\right.$ and $42^{\circ} \mathrm{C}$ ): Yeast cultures were checked for their growth ability at $37^{\circ} \mathrm{C}$ and $42^{\circ} \mathrm{C}$ on GPY agar medium after 4 days, of incubation.

Growth on high osmotic pressure media :Slops were prepared of $1 \%$ yeast extract and $2 \%$ agar some tubes containing $50 \%$ or $60 \%(\mathrm{w} / \mathrm{v})$ glucose or $10 \% \mathrm{NaCl}$ plus $5 \%$ glucose. The slops were inoculated lightly, incubated at $25^{\circ} \mathrm{C}$ and examined for up to 4 weeks.

Tolerance of 1\% acetic acid: A lapful of the cell suspension streaked onto agar plate contain $1 \%$ acetic acid, the plates were incubated at $25^{\circ} \mathrm{C}$, and examined after 3 and 6 days for the development of colonies.

Hydrolysis of urea: Yeast culture were inoculated onto a slant of Christensen's urea agar (Christensen, 1946), compared with control tube of the basal medium without urea. The cultures inspected daily for up to 4 days and the results recorded positive when a deep pink color develops in the tube of test medium but not.

\section{Buffers and solutions used DNA extraction:}

Tris-Borate-EDTA 5X buffer (TBE), $\mathrm{pH}$ 8: This buffer contains $0.29 \mathrm{~g}$ of Na-EDTA, $5.4 \mathrm{~g}$ of Tris$\mathrm{HCl}, 2.75 \mathrm{~g}$ of boric acid and $100 \mathrm{~mL}$ distilled water (pH 8).

\section{Ethidium Bromide Stock Solution}

This solution is composed of $1 \mathrm{~g}$ Ethidium bromide dissolved in $100 \mathrm{~mL}$.

\section{The Loading Dye (5x)}

The loading dye consists of Na-EDTA, pH8.0 (500mM), 2mL glycerol (100\%), 5mL bromophenol blue $(2 \%), 0.75 \mathrm{~mL}$ xylene cyanol $(2 \%) 0.75 \mathrm{~mL}$ distilled water.

\section{Gel Preparation (1\% agarose gel)}

Agarose gel (1\%) is prepared by adding $1 \mathrm{~g}$ of agarose, to $100 \mathrm{~mL}$ Tris-Borate-EDTA (TBE). The solution was boiled to dissolve the agarose in a microwave oven for $1-3 \mathrm{~min}$, and cooled down to $45^{\circ} \mathrm{C}$. then $3 \mu \mathrm{L}$ of ethidium bromide $(1 \%)$ was added and let for solidification at room temperature.

\section{Genomic DNA Extraction}

Total genomic DNA was extracted by using Zymo Research Fungal/Bacterial DNA MiniPrep ${ }^{\mathrm{TM}}$ Kit (Catalog No. D6005) and Thermo Fisher Scientific 
Gene JET Genomic DNA Purification Kit (K0721) were purchased from Sigma Company, Egypt.

\section{Primers used for yeast identification}

Universal primer used: Primer 18SF (5'GCATATCAATAAGCGGAGGAAAAG) and28 SR (5'-GGTCCGTGTTTC AAGACGG).

\section{Specific primer used}

A-The ITS region was amplified using primers ITS1 (5'-TCC GTA GGT GAA CCT GCG G-3') and NL2 (5'-CTC TCT TTT CAA AGT GCT TTT CAT CT-3') according to Baleiras Couto et al. (1996).

B- 5.8SrRNAregion was amplified using primers ITS1 (5'-TCCGTAGGTGAACCTGCGG-3') and ITS4 (5'-TCCTCCGCTTATTGATATGC-3') according to McCullough et al. (1998).

$$
\text { C- Primers NL1 (5'- }
$$
GCATATCAATAAGCGGAGGAAA AG) and NL4 (5'-GGTCCGTGTTCAAGACGG) according to Boekhout et al. (1994).

\section{Molecular identification}

\section{DNA Extraction from Yeast Cells}

A- DNA was extracted according to manufacture instructions using ZR fungal/Bacterial DNA MiniPrep ${ }^{\mathrm{TM}}$ Kit (Catalog No. D6005-ZR crop, India).

B-Yeast genomic DNA purification protocol was carried out according to manufacture instructions using (Thermo Genomic Purification Kit "K0721, USA").

\section{PCR amplification of 26S rRNA gene and 5.8S ITS region}

Amplification reactions were prepared in total volumes of $25 \mu \mathrm{L}$ containing $12.5 \mu \mathrm{L}$ Go Taq Master Mix, a pair of specific primers at the concentration of $0.25 \mu$ molof each primer, $100 \mathrm{ng}$ of Template DNA and nuclease free water up to $25 \mu \mathrm{L}$. PCR apparatus (Medison, USA). The PCR temperature profile was applied as follows: denaturation cycle of $94^{\circ} \mathrm{C}$ for 1 min., followed by 35 cycles of $94^{\circ} \mathrm{C}$ for $30 \mathrm{~s}$. Annealing temperature was tested at $50^{\circ} \mathrm{C}$ for 2 min and extension at $74^{\circ} \mathrm{C}$ for $1.5 \mathrm{~min}$. and a final elongation cycle to $72^{\circ} \mathrm{C}$ for $4 \mathrm{~min}$.

\section{Amplified fragments visualization}

Gel electrophoresis of $1.5 \%(\mathrm{w} / \mathrm{v})$ agarose was used for migrating the amplified DNA fragments. Gels were stained with $0.5 \mu \mathrm{g} / \mathrm{mL}$ ethidium bromide. For elimination, $3 \mathrm{~Kb}$ DNA ladder markers from Thermo Scientific Gene was also loaded on the gel for fragment size comparison.
DNA bands were visualized under UV light and quantified using spectrophotometer (Genway 630).

\section{Purification of PCR products}

The electrophoresed PCR products were purified using Gene JETTMPCR Purification Kit (Thermo, K0701, Germany) gel extraction kit following the manufacture instructions.

\section{Sequence analysis}

PCR product sequencing was achieved by GATC Biotech using ABI 3730xl DNA Sequencer (Konstanz, Germany). Applying forward and reverse primers as will be described by combining the traditional Sanger technology. Sequence similarity search was performed using the NCBI BLAST online tool (http://ncbi.nlm.nih.gov/BLAST/) against the nucleotide collection (nr/nt) database.

\section{Sequences submissions and accessions number}

Sequences of this study have been submitted to NCBI using BankIt tool (http://www.ncbi.nlm.nih.gov/BankIt/)with the published data in the NCBI database accession number.

\section{Phylogenetic tree construction:}

Phylogenetic tree was constructed based on the 18SrRNAintergenicspacers(ITS)sequence comparisons length polymorphism of the PCRamplified and sequences from database using BLAST tree constructed in www.clcbio.com using CIC workbench 7.5 system based on Neighbor Joining method.

\section{RESULTS AND DISCUSSION}

Four yeast strain named Y30, Y42, Y67 and Y72 besides two references strains were traditionally characterized and identified by morphological and physiological criteria according to the keys of identification of Barnett et al. (1990), then they were confirmed and renamed according to Kurtzman and Fell (1998) and Suh et al. (2007).

Their cell morphology and culture characteristics are presented in Table 1. All tested strains possessed oval cells, also two strains (Y67 and Y72) showed cylindrical shape. However, from the data obtained it was shown that strains $Y 30$ and Y42 were vegetative reproduction by multilateral budding beside that Y67 and Y72 strains develop pseudohypha formed by budding and elongation. 
Also, from information gathered in Table (1), it is clearly indicated that all tested strains showed white colonies. In addition, strains Y30 and Y42 showed colony with smooth surface, while the rest cultures formed powdery colonies.

However, the morphological and microscopical examination of the tested strains revealed that some similarities with yeast species already characterized in the literature and with the reference strains as $S$. cerevisiae and G. candidum were observed.

Further physiological analyses were performed for a preliminary identification of the tested strains.

The fermentation tests (Table 2) showed that Y30 and Y42 strains could catabolize glucose, galactose, sucrose and maltose by fermentation while Y67 and Y 72 strains could use no sugar. Moreover, all tested cultures failed to ferment Dxaylose. However, the obvious disparity between the tested cultures could be explained by the fact that various yeast strains showed great variability in their ability to grow on different carbon sources (Barnett et al., 1983).

Regarding the assimilation ability, obvious differences between tested strains were detected (Table 3). It could be gathered from results obtained that all tested cultures assimilated glucose and galactose, our finagling are in agreement with those reported by Hayford and Jespersen (1999). In contrast the tested strains were unable to assimilate lactose, starch, methanol, manitol and citrate. While, only Y30 and Y42 strains could consume either sucrose or maltose.

Moreover, in order to obtain a complete physiological characterization for the tested cultures, assimilation of nitrogen compounds was carried out, where 5 nitrogen compounds were used.

As shown from Table 4, it could be noticed that all tested cultures failed to assimilate either nitrate or nitrite as a sole source of nitrogen. On the other hand, Y67 and Y72 strains were able to assimilate ethylamine and showed different response to Llysine and tryptophan. In contrast, Y30 and Y42 strains were unable to assimilate ethylamine. This finding is consistent with previous results of Rajkowska and Kunicka-Styezynska (2010).

Continuously, serial of complementary tests were carried out in order to complete the physiological features of the tested cultures. Results obtained are tabulated in Table 4. Viewing of these results, it might be observed that growth at non-optimal temperatures $\left(37^{\circ} \mathrm{C}\right.$ and $\left.42^{\circ} \mathrm{C}\right)$ declared that only Y30 strain was able to grow at $37^{\circ} \mathrm{C}$, while the rest tested cultures were failed to grow at $42^{\circ} \mathrm{C}$. This finding means that the tested culture was not thermotolerant, this statement is in contrary with that reported by Ghindea et al. (2009).

In addition, tested strains were examined for resistance to high concentration of glucose. Our results showed that strains $\mathrm{Y} 30$ and $\mathrm{Y} 42$ grew on medium containing $50 \%$. In contrary, Y67 and Y72 strains were failed to grow at ether $50 \%$ or $60 \%$ glucose. In this respect, Ghindea et al. (2000) reported that all tested strains grow well on YPGA medium containing $50 \%$ and $60 \%$ glucose. Furthermore, it was evident from the results obtained that all tested strains failed to grow in medium containing either $10 \% \mathrm{NaCl}+5 \%$ glucose or $1 \%$ acetic acid and failed to hydrolysis urea.

From the foregoing results it could be tested that classical taxonomy analysis showed a great similarity between Y30 and Y42 strains and Saccharomyces cerevisiae according to Barnett et al. (2000), also the present data suggest a possible affiliation between Y67 and Y72 strains and those given for Geotrichum candidum. Four an accurate identification of the studied further molecular analysis is necessary to be done. The first step in this approach was the isolation of plasmid DNA.

In this study three specific primer pairs and one universal primer were used. In silico results showed that two primer pairs (ITS1 - NL2) and (ITS1 - ITS4) exhibited sensitivity and specificity primers for Saccharomyces cerevisiae, while the third specific primer (NL1 - NL4) and the universal primer (18S ITS1-28S ITS1) showed sensitivity and specificity for Geotricum candidum strains.

Results of amplified PCR fragments using 5.8S and $18 \mathrm{~S}$ to four tested yeast strains are shown in Figure (1). The identification of strains was carried out based on ITS1 partial sequence, 5.8S rRNA gene and ITS1 complete sequence and large subunit rRNA gene sequence analysis.

It is very clear from the results obtained that the product of S. cerevisiae scored $600 \mathrm{bp}$ in lan (1and 2) by using $18 \mathrm{~S}$ and primers (ITS1 - NL2) and (ITS1 ITS4). These results agreed with those reported by McCullough et al. (1998). Also, G. candidum scored $600 \mathrm{bp}$ in lan (3 and 4) of PCR using primer (18SITS1-28SITS2) rRNA. Alignments of sequences using BLASTN-NCBI: Alignments sequences of $S$. cerevisiae AA2strain Y30: BLASTN analysis of $S$. cerevisiae $\mathrm{Y} 30$ sequences is shown in Figure (2) using (ITS1-NL2) primer. This obtained sequence produced significant alignment with other accessions of NCBI-databases using BLASTN (http://ncbi.nlm.nih. gov/BLAST/) against 
nucleotide database indicating high similarity with approximately 100 strains of $S$. cerevisiae as shown in Figure (2); whereas it was scored the highest similarity with accession EU268656.1 (99\% identical and $96 \%$ Query cover) and with accessions MG017570.1, MG017580.1 and MG017546.1 (99\% similarity and 99\% Query cover). Alignments sequence of $S$. cerevisiae AAA3 strain Y42: BLASTN analysis of $S$. cerevisiae Y42 sequence was shown in Figure (3). This obtained sequence characterized with significant alignment with other accessions of NCBI-databases using BLASTN (http://ncbi.nlm.nih.gov/BLAST/) against nucleotide database, indicating high similarity to strain of $S$. cerevisiae as shown in Figure (3), whereas it was scored the highest similarity with accession JQ771726.1, HQ443686.1 and KX237671.1 (100\% identical).

Alignments sequence G. candidumGG1 strain Y67. BLAST analysis of G. candidumGG1 Y67 sequence was shown in Figure (4). Against nucleotide database indicating similarity to strain G. candidum, highest similarity was scored with accession MF383368.1 (99\% identical and $98 \%$ Query cover) as shown in Figure (4), and accession numbers JQ713185.1 and JN974267.1 (99\% similarity $100 \%$ Query cover). Alignments sequences of $G$. candidum AAA strain Y72:

BLAST analysis of G. candidum Y72 sequence was shown in Figure (5). The obtained sequence revulted in significant alignment with other accessions of NCBI-databases using BLASTN (http://ncbi.nlm.nih.gov/BLAST/)against nucleotide database indicating similarity to strain of G. candidum. Highest similarity with accession MF383376.1 and KF112070.1 (99\% identical and query coverage 91\%) as shown in Figure (5).

\section{Database submissions and accession numbers.}

Four yeast isolates were molecularly identified as: $S$. cerevisiae AA2, S. cerevisiae AAA3, G. candidum GG1 and G. candidum AAA, their sequence analysis results were submitted to Genebank in the NCBI database. They have been accepted to be deposited and released in Genebank under four new accession numbers as shown in Table (5), and Figures (6-9).

\section{Phylogenetic relationship of the Genus Saccharomyces and Geotrichum}

Phylogenetic tree was constructed based on the $18 \mathrm{~S}$ ribosomal RNA sequence comparisons length polymorphism of the PCR-amplified and sequences from database using BLAST tree construct in https://www.ncbi.nlm.nih.gov/blast/ treeview, based on Fast Minimum Evolution.

\section{CONCLUSION}

The PCR method can allow the highly sensitive detection of specific yeast. Such method possesses a significant impact on the analysis of gut community structure, emphasizing the speciesspecific primers for Saccharomyces spp. Sequencing the $18 \mathrm{~S}-\mathrm{ITS}$ region provides a rapid identification and intraspecific phylogenetic studies of strains Saccharomyces spp. Strains were locally isolated from Egyptian resources to increase the additive value of the Egyptian microbial wealth.

\section{REFERENCES}

Baleiras, M.C., Eijsma, B., Hofstra, H., HuisintVeld, J.H., Van der Vossen, J.M., 1996. Evaluation of molecular typing techniques to assign genetic diversity among Saccharomyces cerevisiae strains. Appl. Environ. Microbiol. 62, 41-46.

Barnett, J.A., Payne, R.W, Yarrow, D., 1990. Yeast Characteristic and Identification. 2nd Edition. Cambridge University Press, Cambridge. p. 1-1002.

Barnett, J.A., Payne, R.W., Yarrow, D., 2000. Yeasts: Characteristics and Identification, 3rd Edition. Cambridge University Press, Cambridge.

Boekhout, T., Kurtzman, C.P., Odonnell, K., Smith, M.T., 1994. Phylogeny of the yeast genera Hanseniaspora (anamorph Kloeckera), Dekkera (anamorph Brettanomyces), and Eeniella as inferred from partial $26 S$ ribosomal DNA nucleotide sequences. Int. J. Systemat. Evol. Microbiol. 44(4), 781-786.

Christensen, W.B., 1946. Urea decomposition as a means of differentiating proteus and paracolon cultures from each other and from Salmonella and Shigella type. L Bacteriol. 52, 461-466.

Ghindea, R., Vassu, T., Stoica, I., Tanase, A.M., Csutak, O., 2009. Preliminary taxonomic studies on yeast strains isolated from dairy products. Rom. Biotechnol. Lett. 14 (1), 41704179.

Guilliermond, A., 2003. Culture, Identification and Microbiology. Watchmaker Publishing p. 167-184, available online at http://books.google.com/ books?id= grtBZELXUH4C.

Josepa, S., Guillamon, J.M., Cano, J., 2000. PCR differentiation of Saccharomyces cerevisiae from Saccharomyces bayanus/Saccharomyces pastorianus using specific primers. FEMS Microbiol. Lett. 193 (2), 255-259.

Kumura, H., Tanoue, Y., Tsukahara, M., Tanaka, T., Shimazaki, K., 2004. Screening of dairy yeast strains for probiotic applications. J. Dairy Sci. 87, 4050-4056.

Kurtzman, C.P., Fell, J.W., 1998. Summary of species characteristics. In: The Yeasts: a Taxonomic Study, $4^{\text {th }}$ Edition, C.P., Kurtzman, Fell, J.W., Elsevier, Amsterdam.

Kurtzman, C.P., 2006. Yeast species recognition from gene sequence analysis and other molecular methods. Mycoscience. 47, 65-71.

Kurtzman, C.P.; Fell, J.W.; Boekhout, T., Robert, V., 2011. Methods for isolation, phenotypic characterization and maintenance of yeasts. In: Kurtzman, C.P, Fell J.W., Boekhout, T., The yeasts, a Taxonomic Study, $5^{\text {th }}$ Edition. Elsevier. Amsterdam.

Lodder, J., Kreger-van, R.I.J., 1952. The Yeasts, a Taxonomic Study. North-Holland, Amsterdam.

McCullough, M.J., Clemons, K.V., McCusker, J.H., Stevens, D.A., 1998. Species identification and virulence attributes of 
Saccharomyces boulardii (nom. inval). J. Clin. Microbiol. 36 (9), 2613-2617.

Ouwehand, A. C., Salminen, S., Isolauri, E. (2002). Probiotics: an overview of beneficial effects. In: Siezen R.J., Kok J., Abee T., Schasfsma G., Lactic Acid Bacteria: Genetics, Metabolism and Applications. Springer, Dordrecht. pp. 279-289.

Pataro, C., Guerra, J.B., Petrillo-Peixoto, M.L., MendonçaHagler, L.C., Linardi, V.R., Rosa, C.A., 2000. Yeast communities and genetic polymorphism of Saccharomyces cerevisiae strains associated with artisanal fermentation in Brazil. J. Appl. Microbiol. 89 (1), 24-31.

Psomas, E., Andrighetto, C., Litopoulou-Tzanetaki, E., Lombardi, A., Tzanetakis, N., 2001. Some probiotic properties of yeast isolates from infant faeces and Feta cheese. Int. J. Food Microbiol. 69 (1-2), 125-133.

Querol, A., Fleet, G., 2006. The yeast handbook: yeast in food and beverages. Springer-Verlog, Berlin.

Rajkowska, K., Kunicka-Styczynska, A., 2010. Probiotic properties of yeasts isolated from chicken feces and kefirs. Pol. J. Microbiol. 59 (4), 257-263.

Suh, S., Zhang, N., Nguyen, N., Gross, S., Blackwell, M., 2007. Lab manual for yeast study. Louisiana State University, LA.

Van der AaKühle, A., Jesperen, L., Glover, R.L., Diawara, B., Jakobsen, M., 2001. Identification and characterization of Saccharomyces cerevisiae strains isolated from West African sorghum beer. Yeast. 18 (11), 1069-1079.

Table 1. Morphological and microscopically characteristics of tested yeast strains.

\begin{tabular}{|c|c|c|c|c|c|c|c|c|c|c|c|c|}
\hline \multirow{4}{*}{$\begin{array}{l}\text { Item } \\
\text { Tested strains }\end{array}$} & \multicolumn{9}{|c|}{ Characteristic of vegetative cells } & \multicolumn{3}{|c|}{ Characteristic of vegetative reproduction } \\
\hline & \multirow{2}{*}{\multicolumn{4}{|c|}{$\begin{array}{l}\text { Growth in solid medium } \\
\text { Description of colonies }\end{array}$}} & \multicolumn{5}{|c|}{ Growth in liquid medium } & \multirow{2}{*}{\multicolumn{3}{|c|}{ budding }} \\
\hline & & & & & \multicolumn{3}{|c|}{ Cell shape } & \multicolumn{2}{|c|}{ Hypha } & & & \\
\hline & Color & Surface & Margin & Elevation & Oval & Spherical & Cylinder & True & Pseudo & Monopolar & Biopolar & Maltilaeral \\
\hline S. cerevisiae* & wh & smoth & entire & Convex & + & - & + & - & - & - & - & + \\
\hline Y30 & wh & smoth & entire & Convex & + & + & - & - & - & + & - & + \\
\hline Y42 & wh & smoth & entire & Convex & + & + & - & - & - & - & - & + \\
\hline G. candidum* & wh & powdery & filament & flat & + & - & + & - & + & - & - & - \\
\hline Y67 & wh & powdery & filament & flat & + & - & + & - & + & - & - & - \\
\hline Y72 & wh & powdery & filament & flat & + & - & + & - & + & - & - & - \\
\hline
\end{tabular}

Table 2. Fermentation profiles of tested yeasts.

\begin{tabular}{|c|c|c|c|c|c|c|}
\hline Tested strains & Glucose & Galactose & Lactose & Sucrose & Maltose & D-xylose \\
\hline S. cerevisiae & + & + & - & + & + & - \\
\hline $\mathrm{Y} 30$ & $\mathrm{~s}$ & + & - & + & + & - \\
\hline $\mathrm{Y} 42$ & $\mathrm{~s}$ & + & \pm & + & + & - \\
\hline G. candidum* & - & - & - & - & - & - \\
\hline Y67 & - & - & - & - & - & - \\
\hline Y72 & - & - & - & - & - & - \\
\hline
\end{tabular}


Table 3. Physiological characterization of tested yeast strains.

\begin{tabular}{|c|c|c|c|c|c|c|c|c|c|c|c|c|c|c|c|c|c|}
\hline \multirow[t]{2}{*}{ Item } & \multirow[b]{2}{*}{ 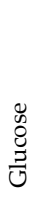 } & \multirow[b]{2}{*}{ 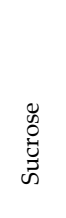 } & \multirow[b]{2}{*}{ 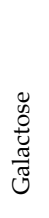 } & \multicolumn{6}{|c|}{ Assimilation of carbon compounds } & \multirow[b]{2}{*}{$\begin{array}{l}\overline{0} \\
\stackrel{0}{0} \\
\stackrel{0}{0}\end{array}$} & \multirow[b]{2}{*}{ 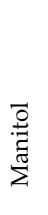 } & \multirow[b]{2}{*}{ 䒕 } & \multicolumn{5}{|c|}{ Assimilation of nitrogen } \\
\hline & & & & 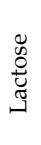 & 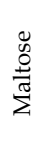 & $\begin{array}{l}\text { త્ } \\
\text { むే屯 }\end{array}$ & 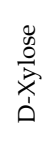 & 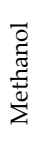 & 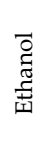 & & & & 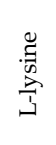 & 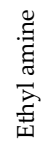 & 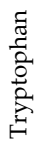 & 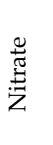 & $\frac{\stackrel{D}{Z}}{\stackrel{ \pm}{Z}}$ \\
\hline \multicolumn{18}{|l|}{ Tested strains } \\
\hline S. cerevisiae* & + & + & + & - & + & - & $\mathrm{W}$ & - & + & - & - & - & - & - & - & - & - \\
\hline Y30 & + & + & + & - & + & - & $w /-$ & - & + & $\mathrm{w}$ & - & - & - & - & - & - & - \\
\hline Y42 & + & + & + & - & + & - & $\mathrm{w} /-$ & - & $\mathrm{w}$ & - & - & - & - & - & - & - & - \\
\hline G. candidum* & + & $+/ w$ & + & - & - & - & + & - & + & + & - & - & $\mathrm{w}$ & + & $\mathrm{w}$ & - & - \\
\hline Y67 & + & w & + & - & - & - & + & - & + & + & - & - & $\mathrm{w} /-$ & + & $\mathrm{w}$ & - & - \\
\hline Y72 & + & $\mathrm{w}$ & + & - & - & - & + & - & + & + & - & - & $\mathrm{w} /-$ & + & $\mathrm{w}$ & - & - \\
\hline
\end{tabular}

*: Reference strain; w: Weak positivew/-: Weakor negative

Table 4. Physiological characterization (complementary tests) of tested yeast strains.

\begin{tabular}{|c|c|c|c|c|c|c|c|c|}
\hline Tested strains & $\begin{array}{l}\text { Growth } \\
\text { at } 37^{\circ} \mathrm{C}\end{array}$ & $\begin{array}{l}\text { Growth } \\
\text { at } 42^{\circ} \mathrm{C}\end{array}$ & Starch formation & $\begin{array}{c}\text { Glucose } \\
50 \%\end{array}$ & $\begin{array}{c}\text { Glucose } \\
60 \%\end{array}$ & $\begin{array}{l}\mathrm{NaCl} 10 \%+ \\
5 \% \text { glucose }\end{array}$ & Acetic acid 1\% & $\begin{array}{l}\text { Hydrolysis } \\
\text { of urea }\end{array}$ \\
\hline S. cerevisiae ${ }^{*}$ & + & - & - & + & $\mathrm{w}$ & - & - & - \\
\hline Y30 & + & - & - & + & w & - & - & - \\
\hline Y42 & $\mathrm{w}$ & - & - & + & $\mathrm{w}$ & - & - & - \\
\hline G. candidum ${ }^{*}$ & $+/ w$ & - & - & $\mathrm{w}$ & - & - & - & - \\
\hline Y67 & $\mathrm{w}$ & - & - & $\mathrm{w} /-$ & - & - & - & - \\
\hline Y72 & w & - & - & $\mathrm{w} /-$ & - & - & - & - \\
\hline
\end{tabular}

*: Reference strain; w: Weak positive w/-: Weakor negative

Table 5. Sequence features and accession numbers.

\begin{tabular}{|c|c|c|c|c|c|c|}
\hline No. & Source & Released Data & Locus & Length & Strain & Accession No. \\
\hline 1 & Raw milk & 11. 1.2017 & $26 \mathrm{~S}$ rRNA & $589 \mathrm{bp}$ & AA2 & KY441458 \\
\hline 2 & Fruit yoghurt & 26. 1. 2017 & $26 \mathrm{~S}$ rRNA & $608 \mathrm{bp}$ & AAA3 & KF380234 \\
\hline 3 & Local cream & 26. 6. 2017 & $26 \mathrm{~S}$ rRNA & $563 b p$ & GG1 & MF383376 \\
\hline 4 & Milk ripe & 26. 6. 2017 & $26 \mathrm{~S}$ rRNA & $686 \mathrm{bp}$ & AAA & MF383368 \\
\hline
\end{tabular}




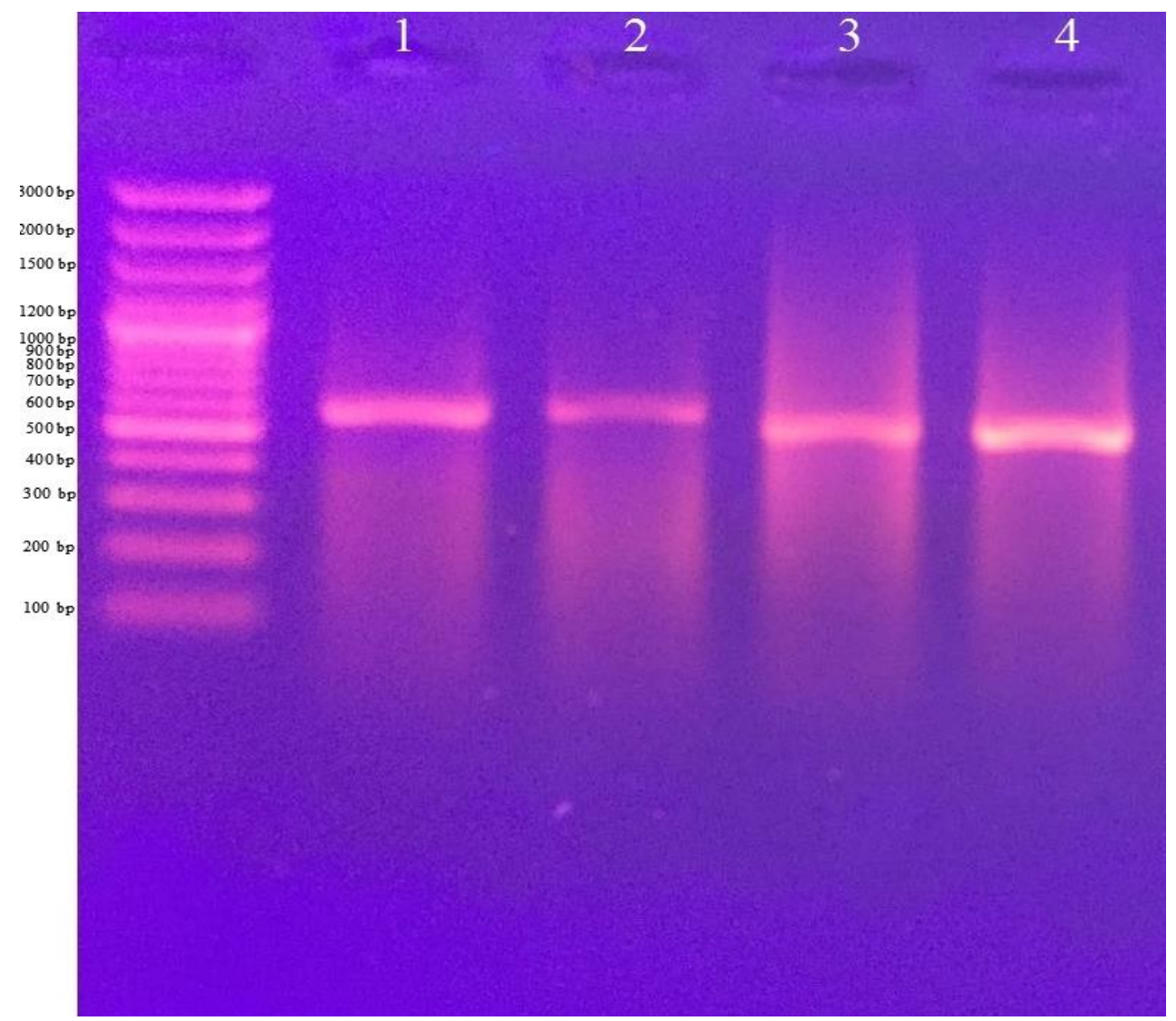

Fig. 1. PCR amplified fragments. (1) using $18 \mathrm{~S}$ for S. cerevisiae AA2, (2) S. cerevisiae AAA3,(3) using $18 \mathrm{~S}$ G. candidum GG1 and (4) G. candidumAAA.

Setect All wone Selectedo

\begin{tabular}{|c|c|c|c|c|c|c|c|}
\hline \multicolumn{8}{|c|}{ 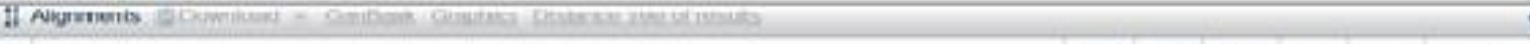 } \\
\hline & Deseripion & $\begin{array}{l}\text { Max } \\
\text { score }\end{array}$ & $\begin{array}{l}\text { Total } \\
\text { score }\end{array}$ & $\begin{array}{l}\text { Query } \\
\text { cover }\end{array}$ & $\frac{E}{\text { vatue }}$ & Went & Accession \\
\hline E & 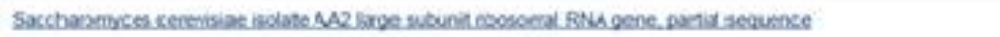 & $10 e d$ & 1008 & $100 \%$ & 00 & $120 \%$ & krestasas. \\
\hline$\nabla$ & 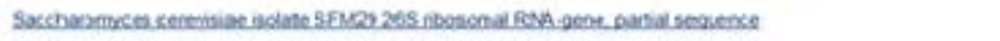 & 1061 & 1061 & $\infty \%$ & 00 & $69 \%$ & MConts701 \\
\hline (B) & 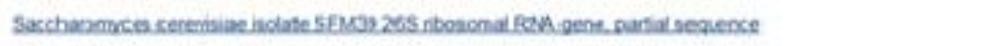 & 1057 & 1057 & $99 \%$ & 00 & 994 & Meorizea \\
\hline [ & 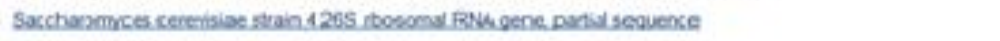 & $105 r$ & 1057 & 994 & 00 & $\cos$ & Hatorere.1 \\
\hline E & 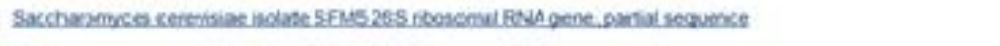 & 1055 & 1055 & $99 \%$ & OD & $19 \%$ & Mcerzsas \\
\hline$\square$ & 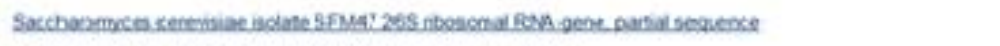 & $10 \$ 3$ & 1053 & $99 \%$ & 00 & $69 \%$ & Mconzses \\
\hline t & 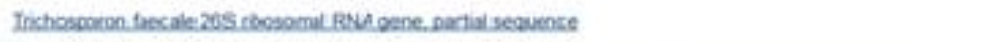 & 1053 & 1053 & 20\% & 00 & $100 \%$ & $10 \times 30051061$ \\
\hline$\nabla$ & 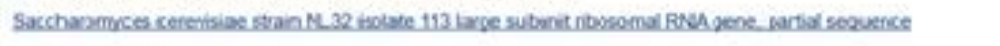 & 1053 & 1053 & $10 \%$ & 00 & $120 \%$ & krsubes \\
\hline E & 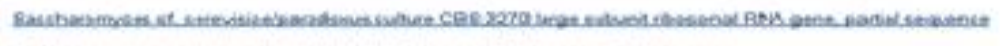 & $106 x$ & 1053 & $\infty 4$ & ob & 604 & crostosies \\
\hline (6) & 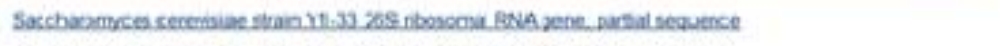 & 1053 & 1053 & $97 \%$ & 00 & 994 & Busazeset \\
\hline [5) & 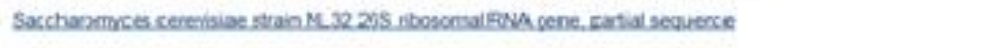 & 1053 & 1053 & $97 \%$ & 00 & $90 \%$ & Hationes.1 \\
\hline ש & 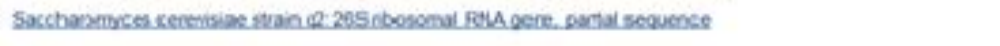 & 1053 & 1053 & $96 \%$ & 00 & $150 \%$ & HMterzen. \\
\hline 무 & 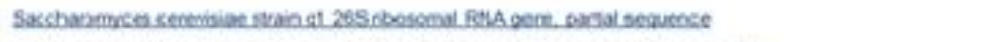 & 1053 & 1053 & $98 \%$ & 00 & $99 \%$ & HM107re9.1 \\
\hline B & 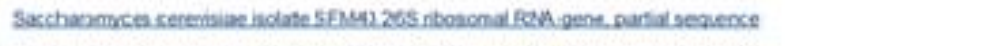 & 1051 & 1051 & $99 \%$ & 00 & 9046 & Moontse4 \\
\hline FII & 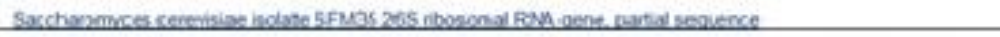 & $105 t$ & 1051 & poest & 00 & wes & 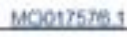 \\
\hline
\end{tabular}

Fig. 2. BLASTN similarity regions and percentage with S. cerevisiae AA2 sequence. 


\begin{tabular}{|c|c|c|c|c|c|c|c|}
\hline \multicolumn{8}{|c|}{ Sehact: Al Norise Selected:0 } \\
\hline & Description & $\begin{array}{l}\text { Max } \\
\text { score }\end{array}$ & $\begin{array}{l}\text { Total } \\
\text { score }\end{array}$ & $\begin{array}{l}\text { Query } \\
\text { cower }\end{array}$ & $\underset{\text { value }}{E}$ & Ident & Accossion \\
\hline [ & 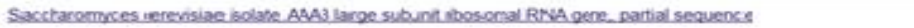 & 1123 & 1123 & $100 \%$ & 0.0 & $100 \%$ & Ms39023s 1 \\
\hline D & 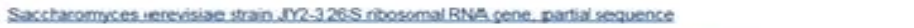 & 1068 & 1058 & $96 \%$ & 0.0 & $99 \%$ & $\operatorname{san} 12301$ \\
\hline E & 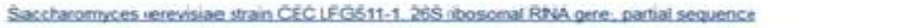 & 1008 & 1080 & $96 \%$ & 0.0 & $09 \%$ & Hod4asesit 1 \\
\hline 口 & 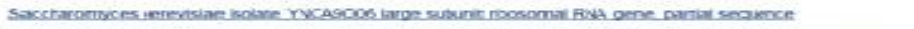 & 1004 & 1004 & asere & 00 & nemb & nozsorilis \\
\hline 口 & 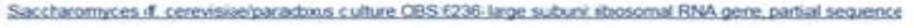 & 1061 & 1051 & $95 \%$ & 0.0 & $99 \%$ & mogeso: 1 \\
\hline a & 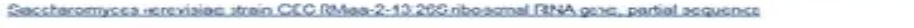 & 1061 & 1051 & 95\% & 0.0 & $00 \%$ & 50032701 \\
\hline ] & 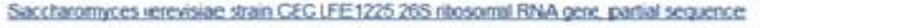 & 1061 & 1001 & $95 \%$ & 0.0 & $89 \%$ & Henstres.1 \\
\hline n & 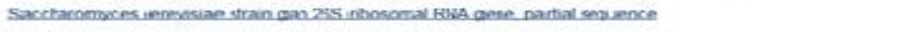 & nes1 & 1061 & sesere & oo & semo & tureessis 1 \\
\hline घ & 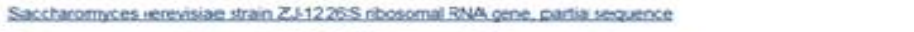 & 1059 & 1059 & $95 \%$ & 0.0 & $99 \%$ & ma3t681. \\
\hline $\mathbf{\square}$ & 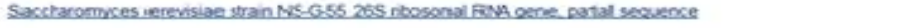 & 1057 & 1057 & $96 \%$ & 0.0 & $99 \%$ & Knag200201 \\
\hline 口 & 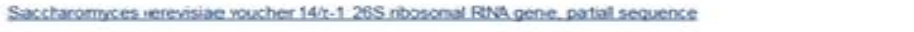 & 1057 & 1057 & $96 \%$ & 0.0 & $99 \%$ & KT:333038 1 \\
\hline 口 & 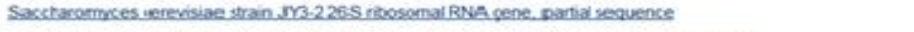 & 1055 & 1055 & $93 \%$ & 0.0 & $100 \%$ & 26712321 \\
\hline$\square$ & 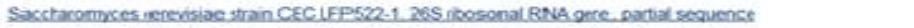 & 1055 & 1055 & $95 \%$ & 0.0 & $99 \%$ & $H 04433685.1$ \\
\hline
\end{tabular}

Fig. 3. BLASTN similarity regions and percentage with S. cerevisiaeAAA3 sequence.

\begin{tabular}{|c|c|c|c|c|c|c|c|}
\hline \multicolumn{8}{|c|}{ Sequences producing significant alignments: } \\
\hline \multicolumn{8}{|c|}{ Select: All None Selectedio } \\
\hline \multicolumn{8}{|c|}{ 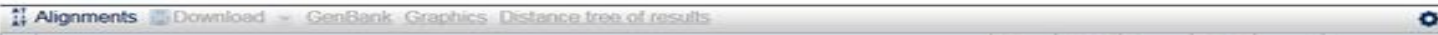 } \\
\hline & Description & $\begin{array}{l}\text { Max } \\
\text { score }\end{array}$ & $\begin{array}{l}\text { Total } \\
\text { score }\end{array}$ & $\begin{array}{l}\text { Query } \\
\text { cover }\end{array}$ & $\begin{array}{c}E \\
\text { value }\end{array}$ & ident & Accession \\
\hline $\boldsymbol{\square}$ & Sectichum candidum isolate GG1 large subunt ribesomal FNA gene. partal seguence & 1040 & 1040 & $100 \%$ & 0.0 & $100 \%$ & MF3233376.1 \\
\hline$\square$ & Sectrishum candidum isolate AAA large subuns riboscomal RovA gene. partal sequence & 1005 & 1005 & $98 \%$ & 00 & $99 \%$ & MF383388.1 \\
\hline ש & 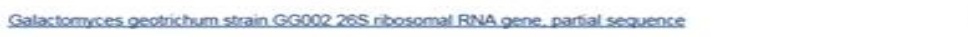 & 996 & 996 & $96 \%$ & 0.0 & $99 \%$ & 202131851 \\
\hline ש & 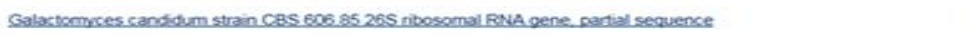 & 996 & 996 & $96 \%$ & 0.0 & $99 \%$ & NN974267.1 \\
\hline $\boldsymbol{\square}$ & Galastomuces gectrichum strain Q1-2.265 nbosomal RNA gere sartial seasence & 996 & 996 & $96 \%$ & 0.0 & $99 \%$ & HMTS44391 \\
\hline$\square$ & Sectichum so. 5.3-1.25S nibosomal Fova gene, partial sequence & 996 & 996 & $96 \%$ & 0.0 & $99 \%$ & EJ473451.1 \\
\hline ש & Seotrichum so XOMOSD 265 ribosomal FNA gene, aribal secuence & 996 & 996 & $96 \%$ & 0.0 & $99 \%$ & EU283419 1 \\
\hline ש & Galactomrces candidum strain Y11.26S nibosomal RNA gene, partial sequence & 994 & 994 & $96 \%$ & 0.0 & $99 \%$ & kens919se.1. \\
\hline$\square$ & 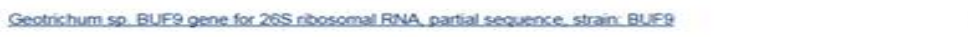 & 992 & 992 & $96 \%$ & 0.0 & $99 \%$ & AB741075. \\
\hline $\boldsymbol{\square}$ & 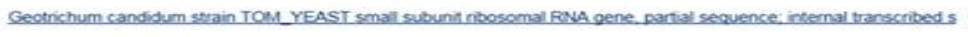 & 990 & 990 & $96 \%$ & 0.0 & $99 \%$ & KF112070.1 \\
\hline घ & Salactormrces canddum zes roosomal RaNA gene. partal sequence & 990 & 990 & $96 \%$ & 0.0 & $99 \%$ & KFO15740 1 \\
\hline घ & Galaxtonmces candidum stran C8S 607 25 265 ribosomal FNA gene. partial sequence & 990 & 990 & $96 \%$ & 0.0 & $99 \%$ & ave742681 \\
\hline$\square$ & 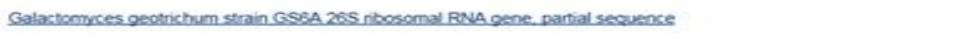 & 990 & 990 & $96 \%$ & 0.0 & $99 \%$ & HMTS44437.1 \\
\hline ש & 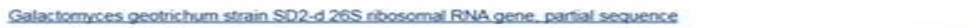 & 990 & 990 & $96 \%$ & 0.0 & $99 \%$ & Hans 44447.1 \\
\hline
\end{tabular}

Fig. 4. BLASTN similarity regions and percentage with Geotrichum candidum GG1 sequence.

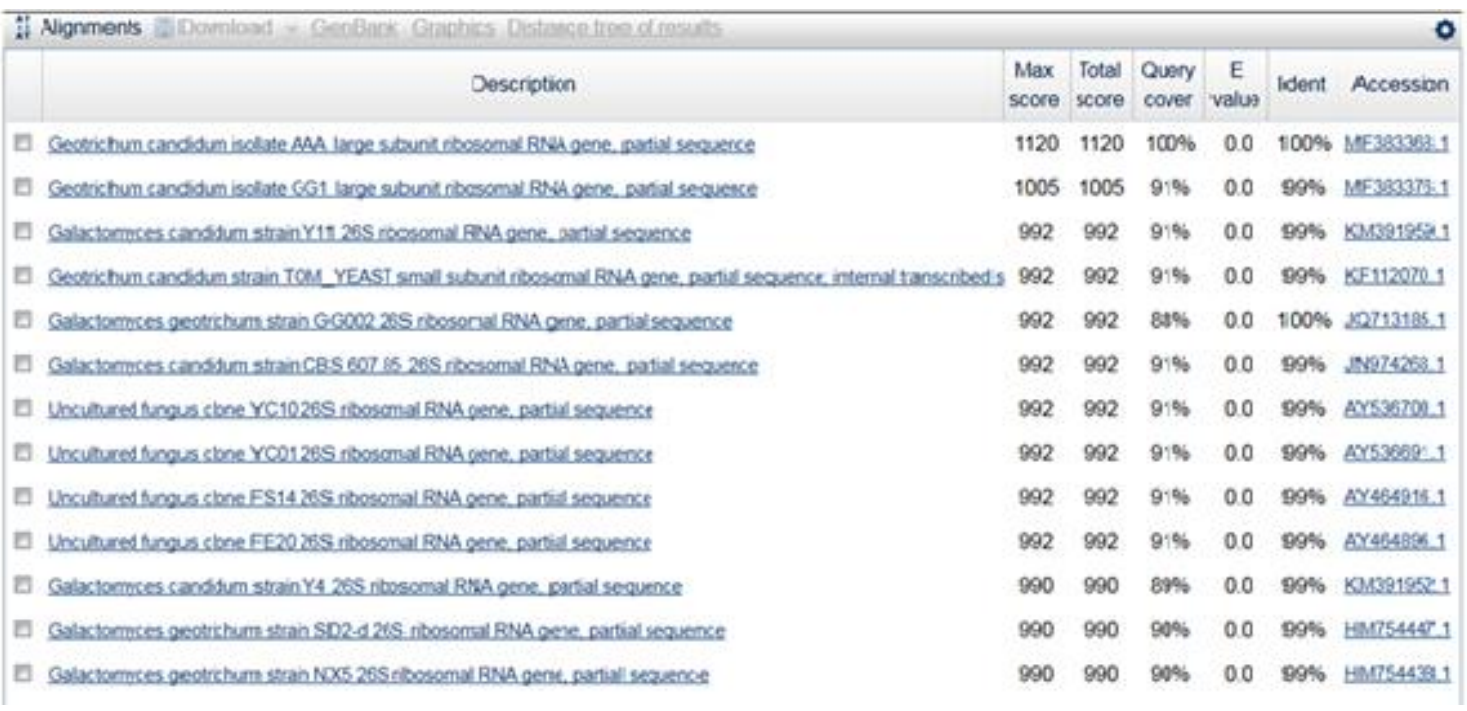

Fig. 5. BLASTN similarity regions and percentage with Geotrichum candidum AAA sequence. 


\section{Saccharomyces cerevisiae isolate AA2 large subunit ribosomal RNA gene, partial sequence}

GenBank: KY441458.1

FASTA Graphics

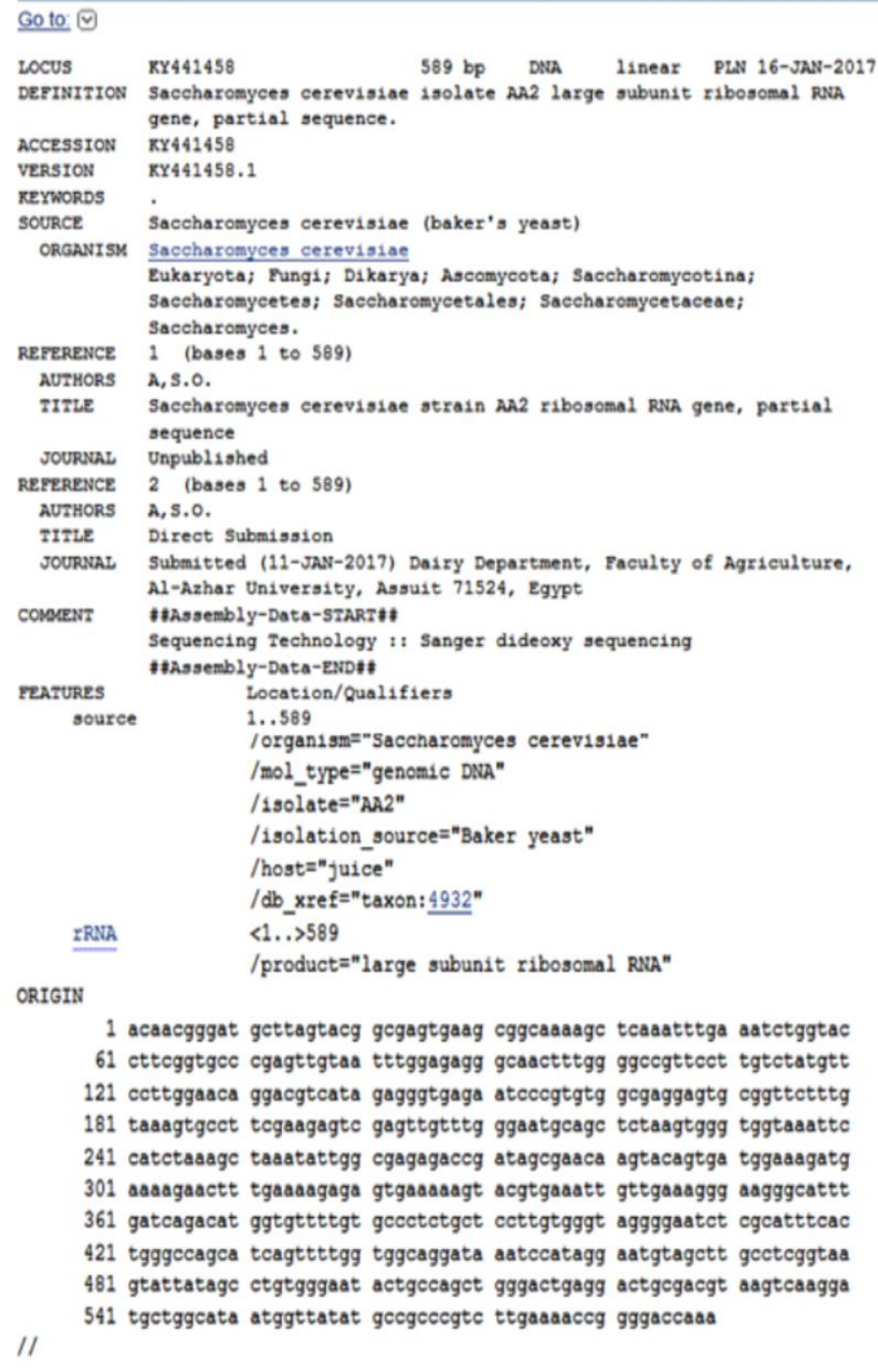

1 acaaegggat gettagtacg gegagtgaag eggeaaage tcaatttga aatetggtac

61 ctteggtgec egagttgtaa tttggagagg geaacttgg ggecgttect tgtetatgtt

121 ccttggaaca ggacgtcata gagggtgaga atccegtgtg gegaggagtg eggttctttg 181 taaagtgect tegaagagtc gagttgtttg ggaatgeage tctaagtggg tggtaaattc 241 catctaaage taaatattgg egagagaceg atagegaaca agtacagtga tggaaagatg 301 aaaagauct tgaaagaga gtgaauagt acgtgaautt gttgaaagg aagggeattt 361 gatcagacat ggtgttttgt gecctctget cettgtgggt aggggaatct egcatttcac 421 tgggccagca tcagttttgg tggcaggata aatccatagg aatgtagctt gecteggtaa 481 gtattatage etgtgggaat actgecaget gggactgagg actgegacgt aagteaagga /I 541 tgetggeata atggttatat gecgecegte ttgaaaceg gggaccaua

Fig. 6. NCBI flat file for Egyptian Sacharomyces cerevisiaeY3018S ribosomal RNA gene, partial sequence. 


\section{Saccharomyces cerevisiae isolate AAA3 large subunit ribosomal RNA gene, partial sequence}

GenBank: MF380234.1

FASTA Graphics

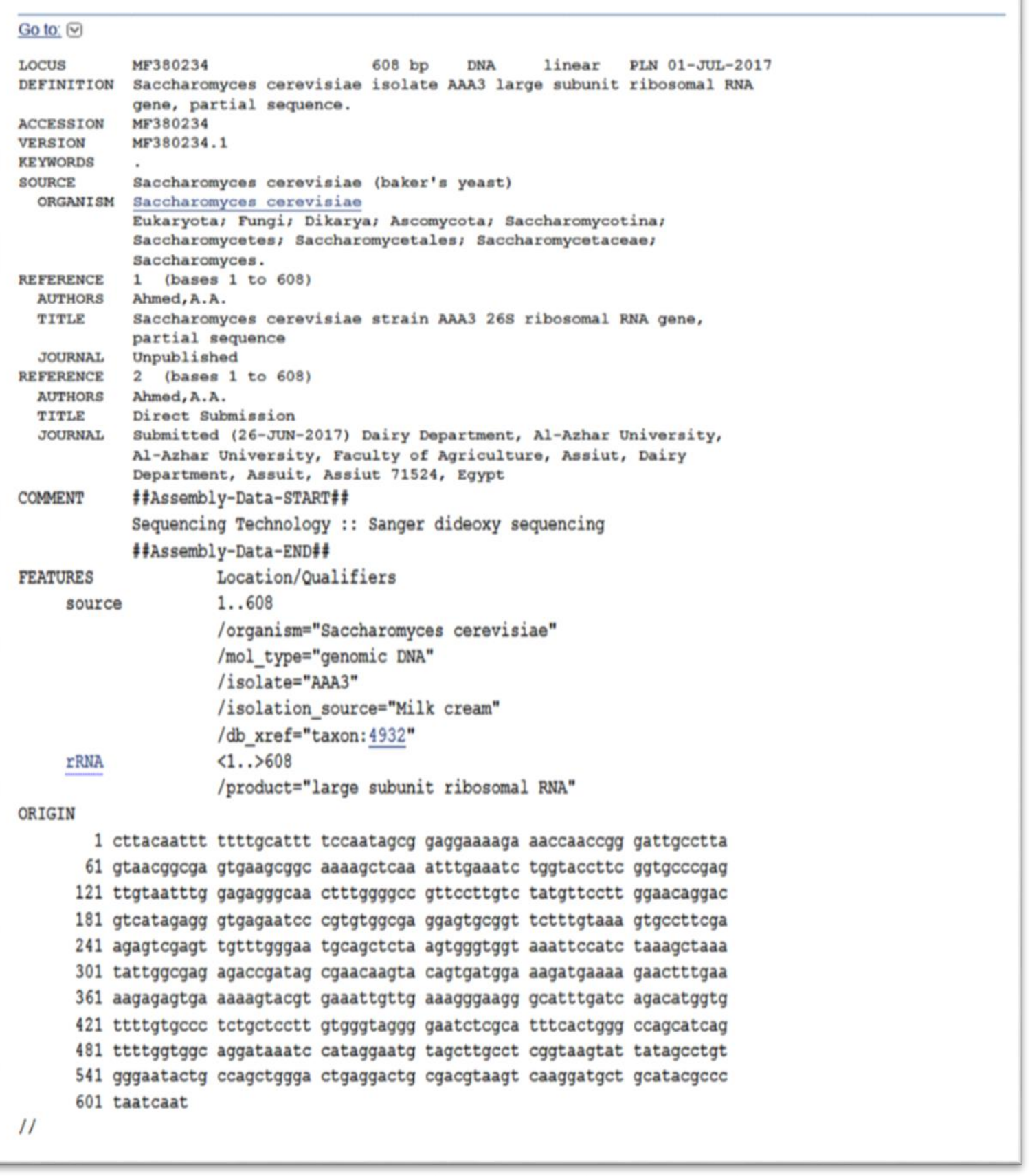

Fig. 7. NCBI flat file for Egyptian Saccharomyces cerevisiaeY42 18S ribosomal RNA gene, partial sequence. 


\section{Geotrichum candidum isolate GG1 large subunit ribosomal RNA gene, partial sequence}

GenBank MF383376.1

EASTA Graphics

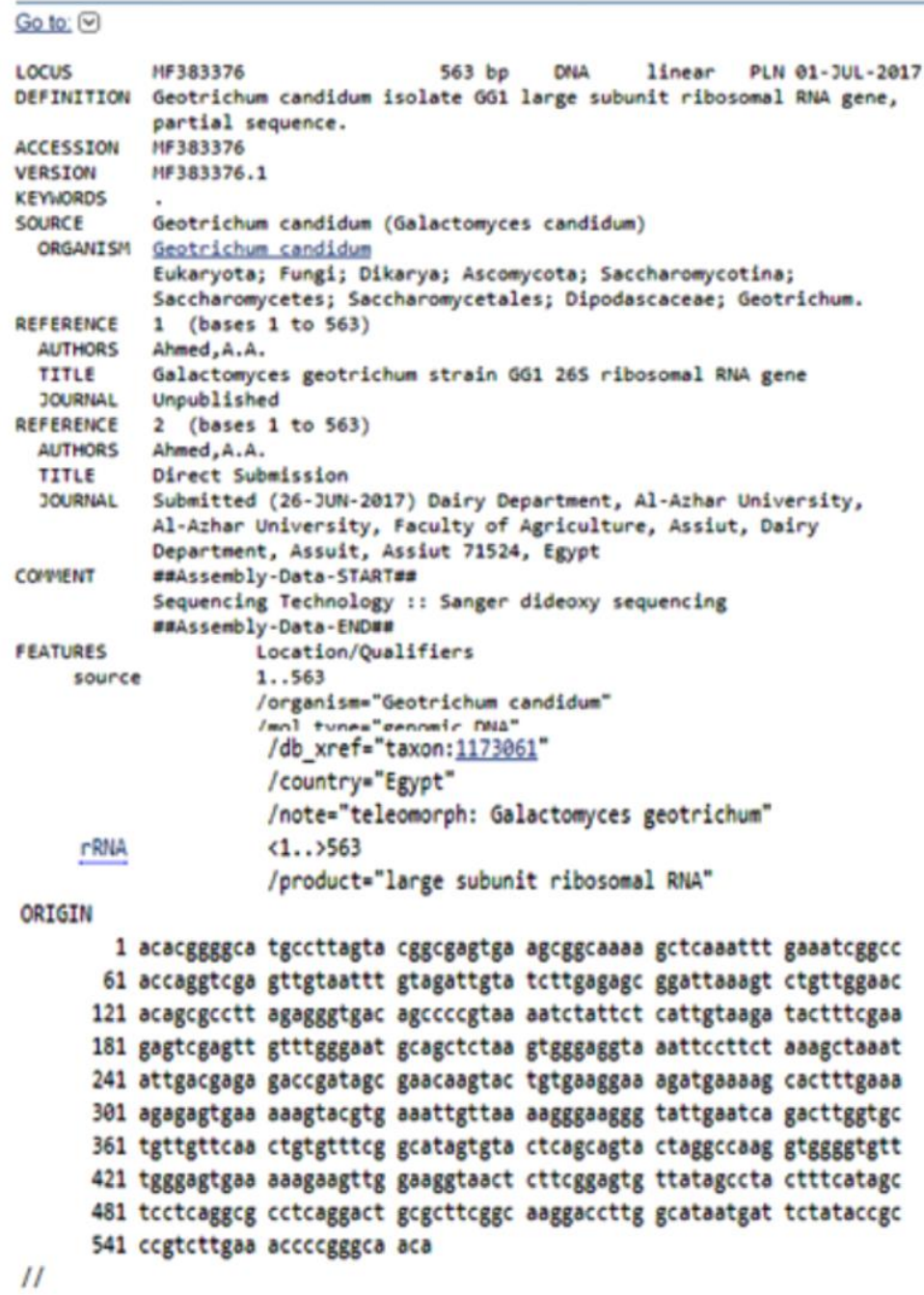

1 acacggggca tgccttagta cggcgagtga agcggcaaaa gctcaaattt gaatcggcc 61 accaggtcga gttgtaattt gtagattgta tcttgagage ggattaoagt ctgttggaac 121 acagcgectt agagggtgac agccccgtaa aatctattct cattgtaaga tactttcgaa 181 gagtcgagtt gtttgggaat gcagctcta gtgggaggta aattccttct asagctaaat 241 attgacgaga gaccgatagc gaacaagtac tgtgaaggaa agatgaasag cactttgaa 301 agagagtgaa aaagtacgtg aasttgttaa aagggaaggg tattgaatca gacttggtgc 361 tgttgttcou ctgtgtttcg gcatagtgto ctcagcagto ctaggccosg gtggggtgtt 421 tgggagtgaa aaagaagttg gaaggtaact cttcggagtg ttatagccta ctttcatagc 481 tcctcaggcg cctcaggact gcgcttcggc aaggaccttg gcataatgat tctataccgc // 541 cegtcttgas accecgggca aca

Fig. 8. NCBI flat file for Egyptian Geotrichum candidum Y67 18S ribosomal RNA gene, partial sequence. 


\section{Geotrichum candidum isolate AAA large subunit ribosomal RNA gene, partial sequence}

GenBank: MF383368.1

EASTA Graphis

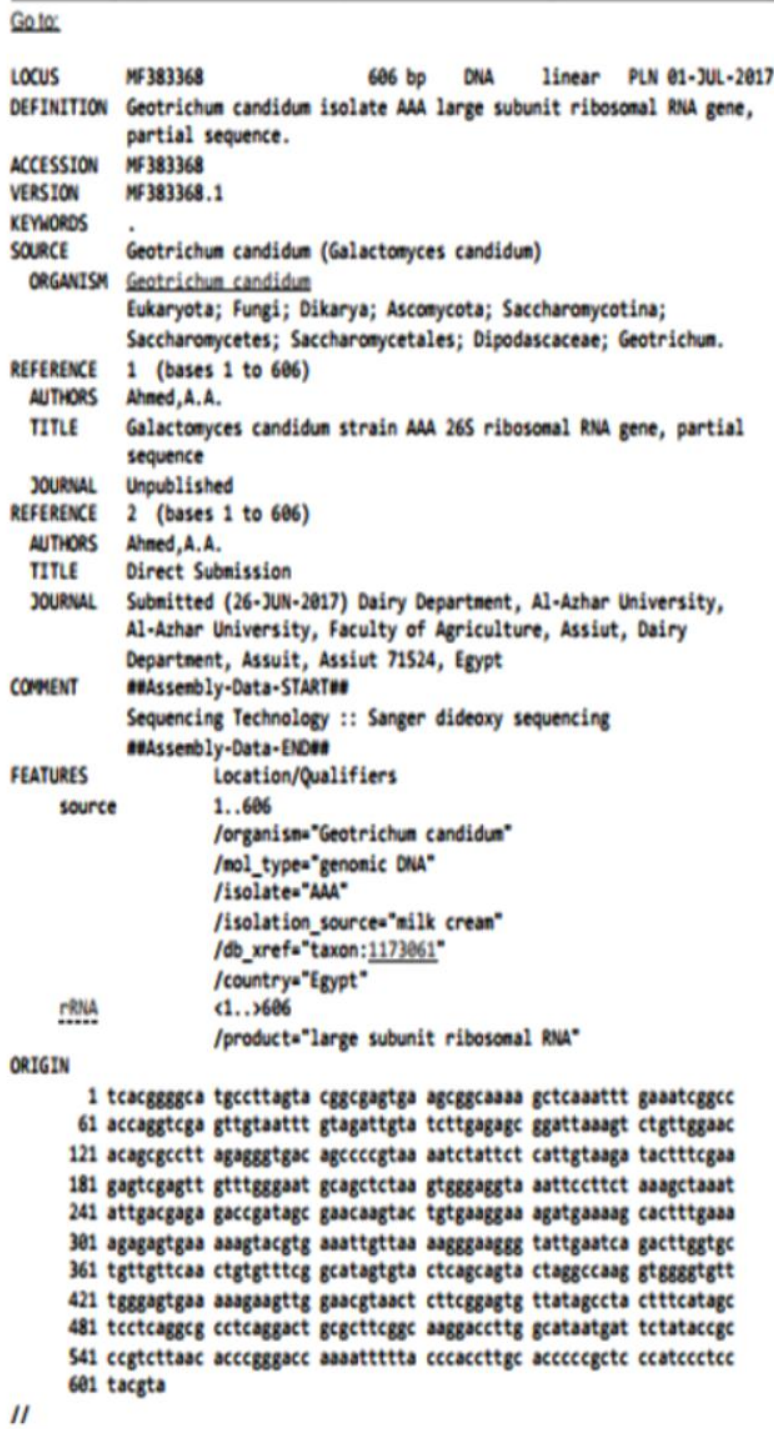

Fig. 9. NCBI flat file for Egyptian Geotrichum candidum Y72 18S ribosomal RNA gene, partial sequence. 


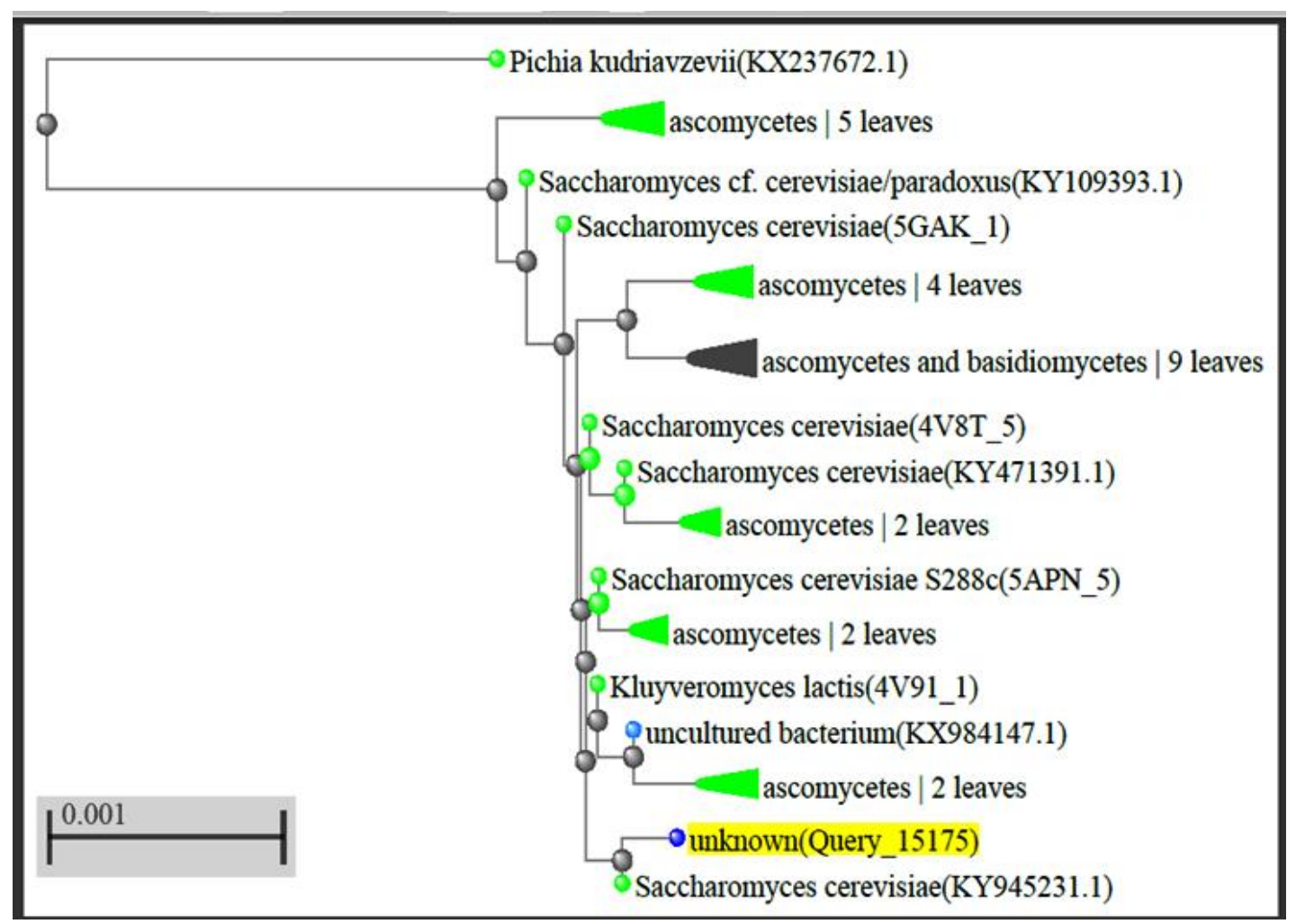

Fig. 10. Phylogenetic tree based on sequence distance analysis of 589bp positions of the $18 \mathrm{~S}$ rDNA region in Saccharomyces cerevisiae strain Y30.

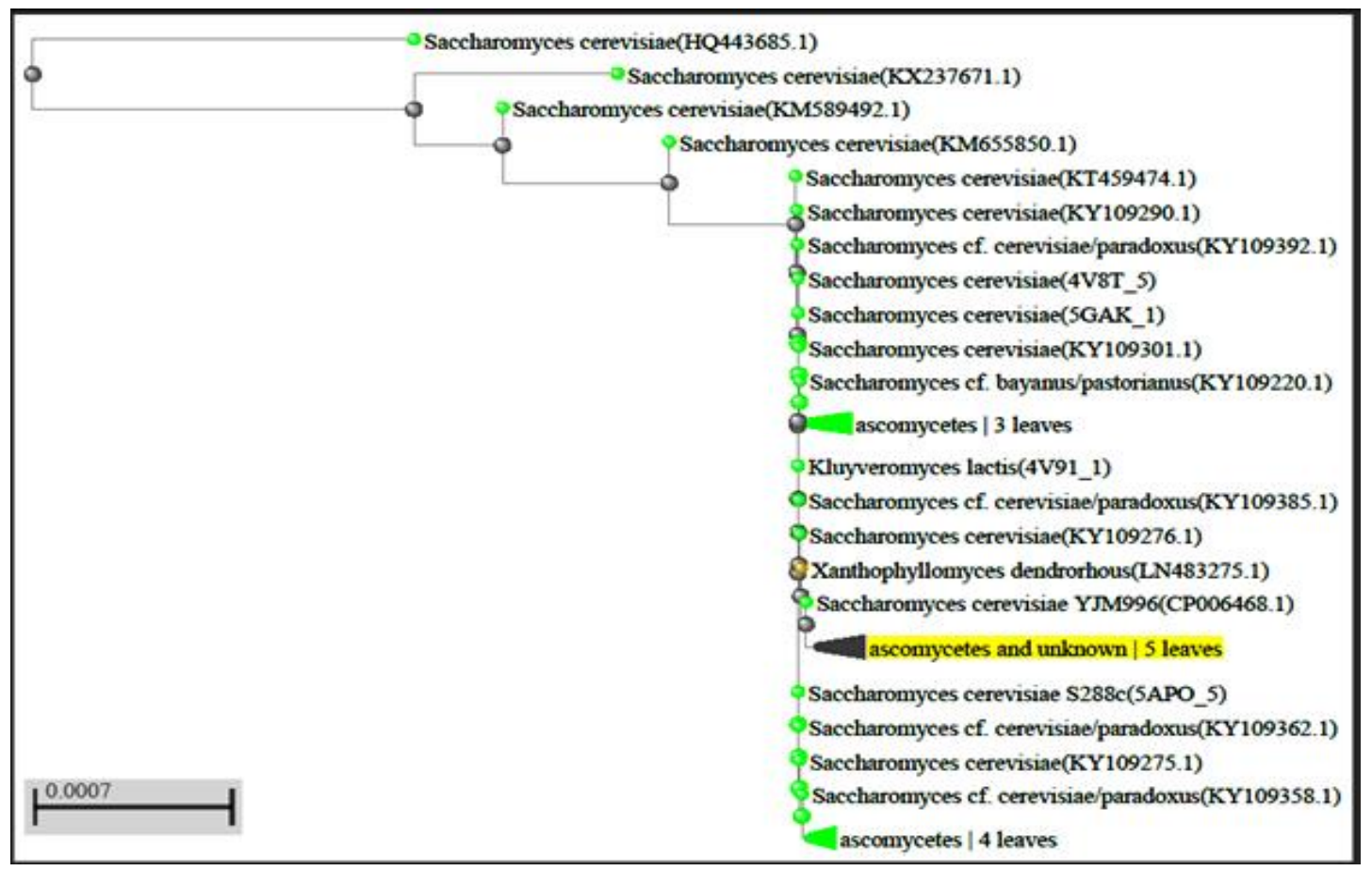

Fig. 11. Phylogenetic tree based on sequence distance analysis of $608 \mathrm{bp}$ positions of the $18 \mathrm{~S}$ rDNA-ITS2 region in Saccharomyces strain Y42. 


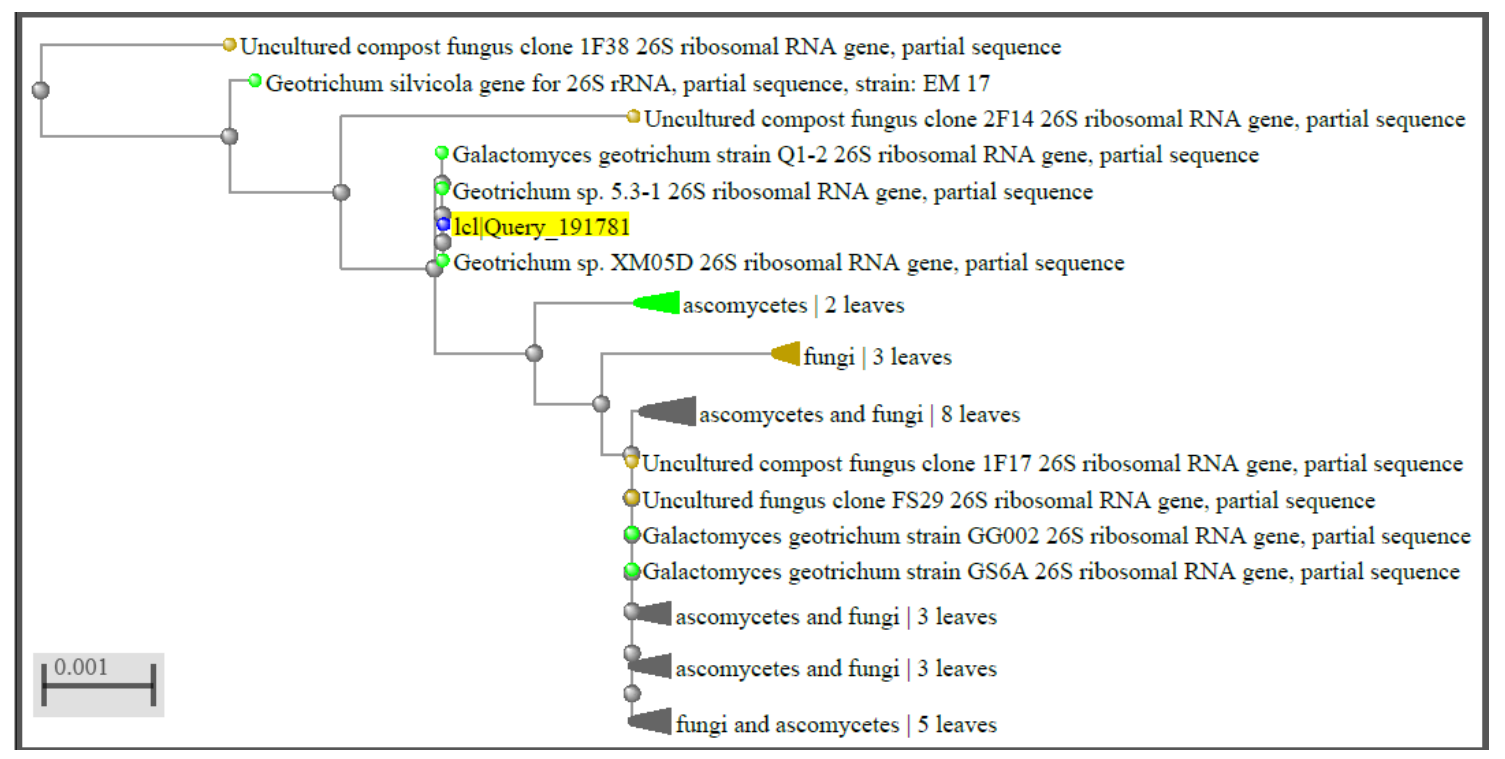

Fig. 12. Phylogenetic tree based on sequence distance analysis of 563bp positions of the ITS1-18S rDNA-ITS2 region in Geotrichum candidum strain Y67.

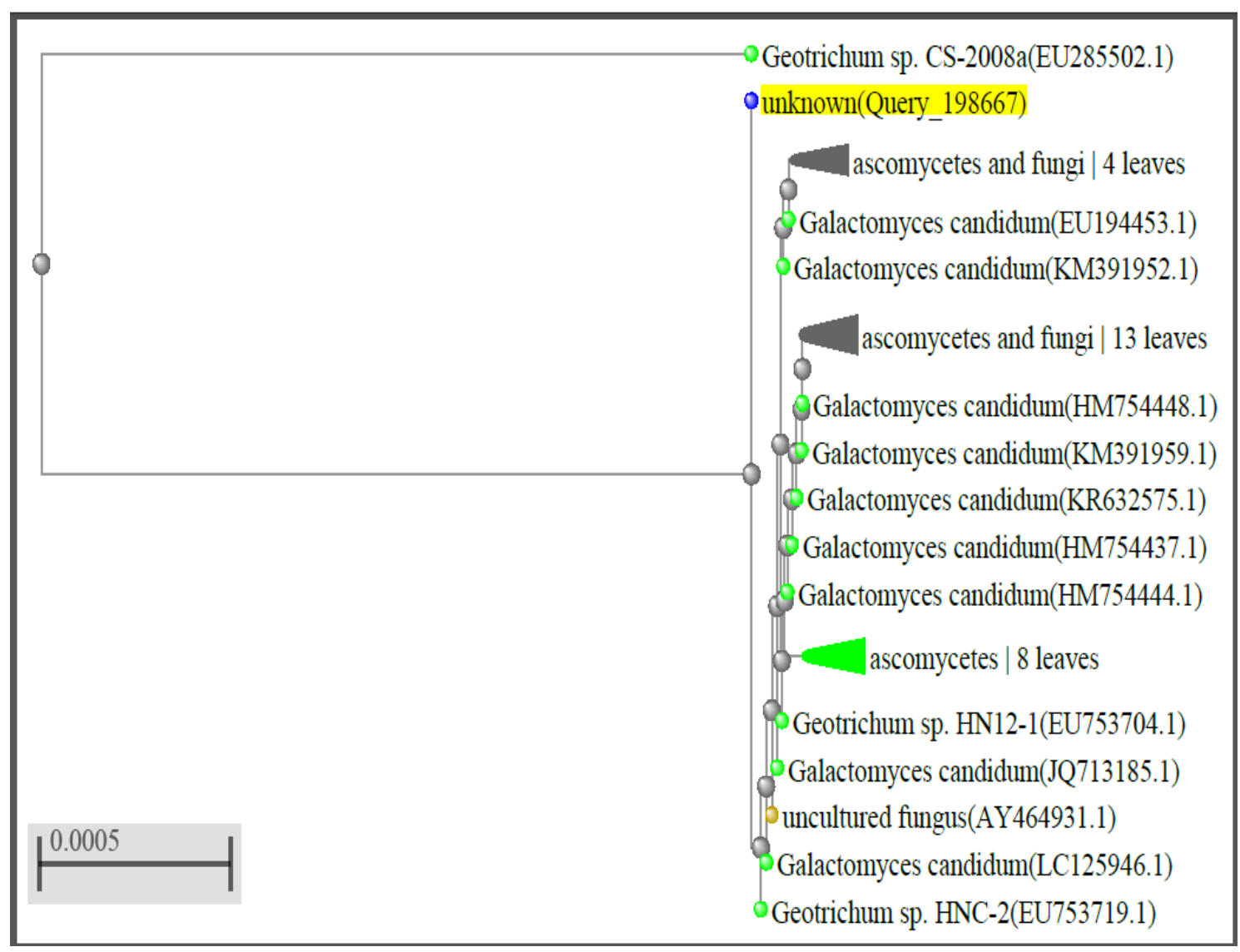

Fig. 13. Phylogenetic tree based on sequence distance analysis of 606bp positions of the ITS1-18S rDNA-ITS2 region in Geotrichum candidum strain Y72. 


\title{
التعريف بالصفات المظهرية والجينية للخجائر المعزولة من بعض منتجات الالبان
}

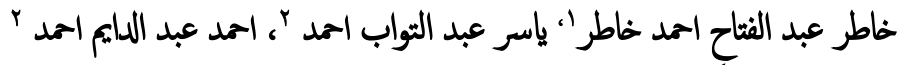

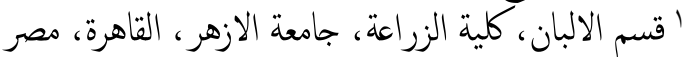

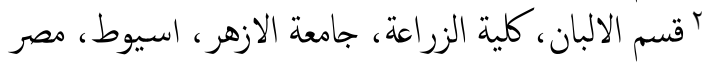

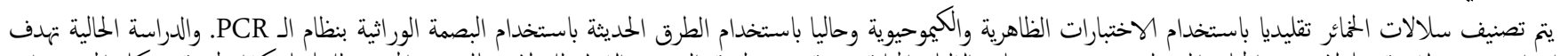

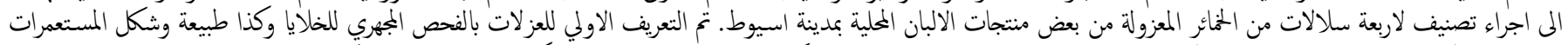

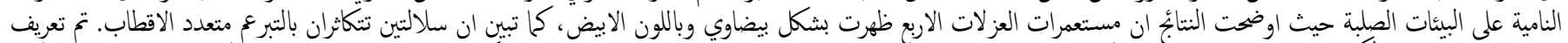

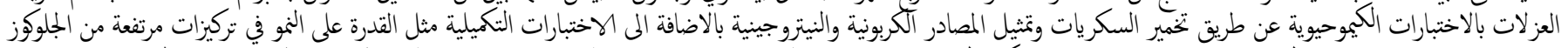

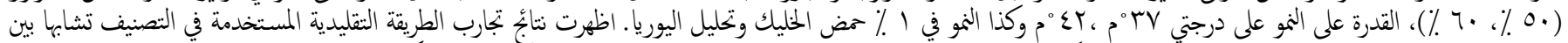

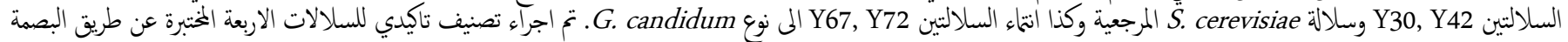

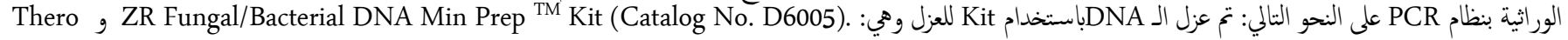

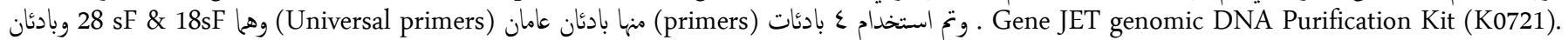

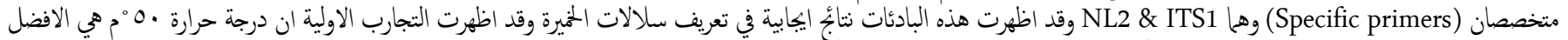

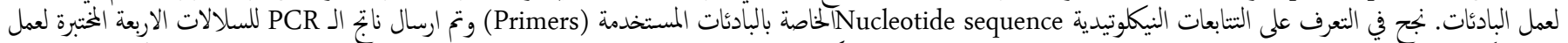

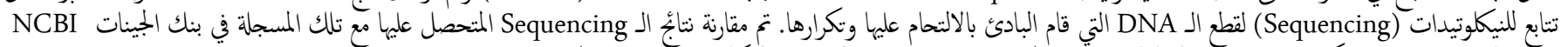

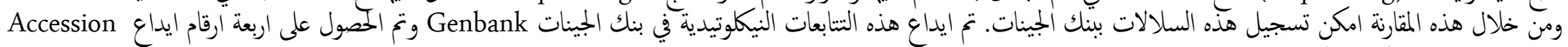

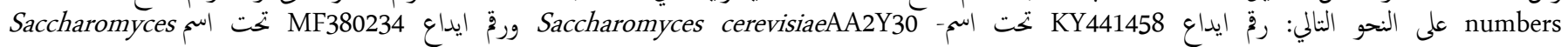

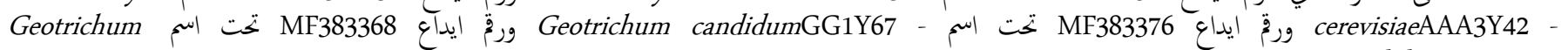
.candidumAAAY72 - 